\title{
MODEL PENERAPAN GOOD CORPORATE GOVERNANCE DALAM PRAKTIK TUNNELING DI INDONESIA
}

\author{
Dewi Diah Fakhriyyah \\ Universitas Islam Malang \\ dewi.d.fakh@gmail.com \\ M. Cholid Mawardi \\ Universitas Islam Malang \\ m.cholid165@gmail.com
}

$$
\begin{aligned}
& \text { Didaftarkan : } 13 \text { Juli } 2020 \\
& \text { Direview }: 2 \text { Desember } 2020 \\
& \text { Diterima } \quad: 20 \text { Desember } 2020
\end{aligned}
$$

\begin{abstract}
This study aims to examine the effect of corporate governance, company size, leverage, and profitability on tunneling as a form of agency conflict and the role of dividend policy in moderating the effect of corporate governance on tunneling. The analysis technique used is a moderation regression analysis. The population was a public company listed on the Indonesia Stock Exchange (IDX) during 2013-2017 and the sample was selected by judgment sampling technique. The results showed that corporate governance can minimazing the occurrence of tunneling, and company size and profitability increase the practice of tunneling, but leverage can not affect tunneling. Dividend policy as a moderating variable in this study can not moderate the influence of corporate governance on tunneling problem. This is due to dividend policy in developing countries such as Indonesia which is a form of substitution of companies in overcoming agency problems such as tunneling.
\end{abstract}

\section{Keywords: Corporate governance, tunneling, dividend policy, agency theory}

\begin{abstract}
ABSTRAK
Penelitian ini bertujuan menguji pengaruh corporate governance, ukuran perusahaan, leverage, dan profitabilitas terhadap tunneling sebagai bentuk konflik keagenan serta peran kebijakan dividen dalam memoderasi pengaruh corporate governance terhadap tunneling.Teknik analisis yang digunakan adalah analisis regresi moderasi.Populasi penelitian adalah perusahaan publik yang terdaftar di Bursa Efek Indonesia (BEI) selama tahun 2013-2017 dan
\end{abstract}


sampel dipilih menggunakan teknik judgement sampling. Hasil penelitian menunjukkan bahwa corporate governance mampu meminimalkan terjadinya tunneling, serta ukuran perusahaan dan profitabilitas justru memperbesar terjadinya praktik tunneling, namun leverage tidak berpengaruh terhadap tunneling. Kebijakan dividen sebagai variabel moderasi dalam penelitian ini tidak mampu memoderasi pengaruh corporate governance dalam mengatasi masalah tunneling. Hal ini disebabkan kebijakan dividen di Negara berkembang seperti Indonesia merupakan bentuk substitusi dari perusahaan dalam mengatasi masalah agensi seperti tunneling.

\section{PENDAHULUAN}

Transaksi pihak berelasi yang terjadi di perusahaan merupakan hal yang lazim terjadi, namun pada negara-negara berkembang isu transaksi pihak berelasi menjadi hal kritis karena rendahnya perlindungan pemegang saham di negara-negara berkembang termasuk Indonesia.Hal ini terjadi karena Indonesia merupakan negara civil law dan sifat kepemilikan yang terkonsentrasi sehingga kondisi ini menyebabkan terjadinya agency problem antara pemegang saham mayoritas dan minoritas (agency problem tipe II).Transaksi pihak berelasi yang lazim terjadi dapat digunakan sebagai bentuk agency problem melalui praktik tunneling.

Beberapa hasil penelitian empiris yang mendeteksi adanya tunneling melalui transaksi pihak berelasi, antara lain, Nurazi, Santi dan Usman (2015), Johnson, et al. (2000), Friedman, et al. (2003), Cheung, Jing, Lu, Rau, dan Stouraitis(2009), dan Juliarto, Tower, Zahn, dan Rusmin (2013). Transaksi pihak berelasi yang merugikan dapat dipandang sesuai dengan hipotesis konflik kepentingan yang merupakan salah satu dari konflik dari teori keagenan (Gordon, Henry, dan Palia, 2004).

Contoh kasus tunneling pada PT Adaro yang menjual batubara dibawah harga pasar pada perusahaan afiliasinya Coltrade Service International, Pte yang merugikan pemegang saham minoritas Adaro dan menguntungkan pemegang saham pengendali PT Adaro dan Coaltrade. 
Jurnal Riset Akuntansi Aksioma

Vol. 19, No. 2, Desember 2020

Berdasarkan agency theory, praktik tunneling dapat diatasi dengan corporate governanceHamid, Ting, \& Kweh(2016), Yeh, Shu, \& Su (2012), Lo, Wong dan Firth (2010), Hastori et al., (2015). Namunpenelitian Juliarto et al. (2013) menyimpulkan bahwa mekanisme corporate governance berupa corporate governance tingkat nasional, struktur kepemilikan asing, serta direktur independen tidak efektif untuk mengendalikan tunneling. Begitu pula dengan penelitian Sari, Djajadikerta, \& Baridwan (2014) yang menyimpulkan bahwa mekanisme corporate governance (struktur kepemilikan, direktur independen, dan komite audit) bukanlah faktor yang efektif untuk mencegah terjadinya praktik tunneling.

Karakteristik perusahaan seperti ukuran perusahaan dan profitabilitas juga dapat dijadikan faktor yang mempengaruhi terjadinya tunneling. Beberapa penelitian terkait ukuran dan profitabilitas terkait dengan tunneling misalnya penelitian Berkman, Cole, \& Fu (2009) menemukan bahwa perusahaan yang lebih kecil berpotensi lebih kecil untuk melakukan tunneling sehingga perusahaan yang lebih besar cenderung lebih mudah melakukan tunneling atas aset yang ada namun perusahaan dengan profitabilitas dan pertumbuhan yang tinggi cenderung untuk terhindar dari praktik tunneling.

Dalam perspektif keagenan khususnya agency theory-free cash flow hypothesis, leveragedan dividen dapat digunakan untuk mengatasi masalah keagenan khususnya terkait dengan agency theory-free cash flow hypothesis. Leveragedan dividen digunakan untuk menahan kas bebas yang ada yang berpotensi dimanfaatkan oleh agen dalam memperkaya dirinya(Jensen, 1986). Hal senada diungkapkan juga dari hasil penelitian Faccio, Larry, Lang, \& Young (2001) dan Cesari (2012). Penelitian Pratiwi (2018) menyatakan bahwa leverage berpengaruh positif terhadap transfer pricing sebagai bentuk masalah tunneling.

Masih sering terjadinya praktik tunneling di Indonesia membuat peneliti termotivasi untuk meneliti model penerapan corporate governance terhadap 
praktik tunneling dan menambahkan juga variabel lain berupa ukuran perusahaan, profitabilitas, leverage, serta meneliti peran kebijakan dividen untuk memoderasi peran corporate governance terhadap praktik tunneling.

TELAAH LITERATUR DAN PENGEMBANGAN HIPOTESIS AGENCY THEORY

Agency conflict disebabkan terpisahnya kepemilikan dan pengelolaan.Teori keagenan merupakan turunan teori permainan (game theory) yang mendesain kontrak antara prinsipal dan agen untuk mengatasi konflik kepentingan atau konflik agensi untuk mencapai kesepakatan yang baik.Agency conflict yang terjadi antara pemilik saham dan manajer merupakan agency conflict tipe I (Jensen dan Meckling, 1976). Perusahaan di Asia termasuk Indonesia tidak mengalami agency conflict tipe I melainkan agency conflict tipe II yaitu terjadi antara pemegang saham mayoritas dan minoritas karena struktur kepemilikan perusahaan yang terkonsentrasi. Pemegang saham mayoritas memiliki pengendalian yang lebih besar sehingga berpotensi melakukan praktik tunneling terhadap pemegang saham minoritas (Cahyani dan Sanjaya, 2014).

Berdasarkan agency theory, mekanisme corporate governance dapat dipertimbangkan untuk membatasi masalah agensi (Kultys, 2016). Dengan penerapan good corporate governance membuat perusahaan berjalan baik dengan memperhatikan hak-hak pemegang saham serta stakeholder lain sehingga dapat menurunkan risiko praktik tunneling oleh pemegang saham mayoritas

\section{TRANSAKSI PIHAK BERELASI DANPRAKTEK TUNNELING}

Transaksi pihak berelasi adalah suatu pengalihan sumber daya, jasa, atau kewajiban antara entitas pelapor dengan pihak-pihak berelasi, terlepas apakah ada harga yang dibebankan.Gordon, Henry, dan Palia (2004) membagi transaksi pihak berelasi menjadi dua hipotesis, yaitu yang bersifat merugikan 
(abusive) dan bersifat menguntungkan (efficient). Dalam penelitian ini transaksi pihak berelasi yang digunakan adalah yang bersifat merugikan berdasarkan hipotesis konflik kepentingan yang merupakan bagian dari teori keagenan.Transaksi pihak berelasi yang bersifat merugikan dapat berupa praktik tunneling. Contoh praktik tunneling dapat berupa self dealing transaction seperti jaminan pinjaman, penjualan aset, keuntungan transfer pricing serta juga melalui peningkatan kepemilikan pemegang saham mayoritas melalui pengeluaran saham dilutive, minority freezeout, dan transaksi lain yang mendiskriminasi pemegang saham minoritas (Johnson et al., 2000). Transaksi pihak berelasi yang umumnya terjadi di Asia berpotensi digunakan sebagai salah satu cara perampasan hak pemegang saham mayoritas (Johnson et al., 2000; Matinfard, Hassani, \& Elyasi (2015); Hasnan, Daie, \& Hussain (2016)).

\section{CORPORATE GOVERNANCE}

Corporate Governance digunakan dalam teori agensi untuk memastikan bahwa agen telah bertindak sesuai dengan keinginan prinsipal demi kepentingan perusahaan.Lima prinsip dasar tata kelola yang baik adalah transparansi, akuntabilitas, pertanggungjawaban, independensi, dan kesetaraan dan kewajaran.

Claessens dan Fan (2003) menyimpulkan bahwa mekanisme corporate governance konvensional dianggap belum cukup mampu untuk mengatasi masalah agensi di Asia, oleh karena itu diperlukan mekanisme corporate governance lain yang dapat menyempurnakan corporate governance konvensional dalam mengatasi masalah agensi di Asia. Beberapa tahun terakhir ini telah berkembang penilaian corporate governance yang melibatkan semua aspek komponen corporate governance. Penelitian ini menggunakan skor corporate governance yang dikembangkan oleh Forum Corporate Governance Index (FCGI) berupa Corporate Governance Self - Assessment Checklist yang menilai pada lima bidang tata kelola, yaitu hak-hak pemegang 
saham, kebijakan tata kelola, praktik tata kelola, pengungkapan, dan fungsi audit.

Hasil penelitian Hamid et al., (2016) menemukan bahwa mekanisme corporate governance yang terdiri dari jumlah direktur independen pada komite audit dan terdapatnya pemisahan jabatan posisi CEO dan chairman (presiden direktur) akan mengurangi tingkat tunneling di Malaysia.

PenelitianHastori et al., (2015) menunjukkan hasilbahwa dewan komisaris dan dewan direksi dapat mengurangi praktik tunneling tetapi komite audit dan komisaris independen tidak signifikan dalam mengurangi praktik tunneling. PenelitianChen et al., (2014) di China menyatakan bahwa jaringan dewan direksi independen sebagai bentuk mekanisme corporate governance mampu menurunkan praktik tunneling. PenelitianYeh et al. (2012) memberikan hasil bahwa tunneling dapat dibatasi dengan praktik corporate governance menggunakan indeks corporate governance. Penelitian Matinfard et al., (2015) menunjukkan hasil bahwa mekanisme corporate governance berperan untuk mengatasi abusive transaction related party yang dapat menurunkan kinerja perusahaan. Sementara itu, hasil yang berbeda ditunjukkan oleh (Sari dan Taman (2011) menunjukkan bahwa mekanisme corporate governance tidak mampu menurunkan kecenderungan risiko tunneling pada aktivitas merger dan akuisisi. Peneliti mengindikasikan penyebab tidak terdukungnya hipotesis disebabkan pengukuran corporate governance menggunakan struktur kepemilikan bukan efektivitas corporate governance.

\section{LEVERAGE}

Leverage digunakan untuk menjelaskan penggunaan utang untuk membiayai aset perusahaan. Jensen (1986) merumuskan agency theory - free cash flow hypothesis yang menyatakan bahwa pembayaran dividen dan pembayaran utang akan mengurangi konflik keagenan antara prinsipal dan agen. Perusahaan dengan leverage tinggi akan lebih terkontrol dalam penggunaan kas karena kas digunakan untuk membayar utang beserta 
bunganya, yang akan mencegah transfer kekayaan kepada pemegang saham. Selain itu, utang dan dividen merupakan substitusi dalam mengendalikan masalah keagenan (Faccio, et al., 2001).

Penelitian Pratiwi (2018) menyatakan bahwa leverage berpengaruh positif terhadap transfer pricing sebagai bentuk masalah tunneling. Hasil penelitian Halim dan Wardhani (2013) menyatakan bahwa semakin tinggi leverage dapat diselaraskan dengan kebijakan dividen yang lebih rendah untuk mensubstitusi biaya keagenan, dalam hal ini kebijakan dividen sebagai bentuk tunneling perusahaan yang mana jika perusahaan melakukan tunneling cenderung membagi dividen lebih kecil atau bahkan tidak membagikan. Faccio et al. (2010) menduga bahwa banyak pemegang saham besar dapat membatasi pemegang saham pengendali dari mengadopsi kebijakan penghancuran nilai, seperti leverage yang berlebihan, terutama ketika perlindungan hukum bagi pemegang saham minoritas lemah.

\section{UKURAN PERUSAHAAN}

Ukuran perusahaan merupakan ukuran atau besar kecilnya aset yang dimiliki perusahaan. Hasil penelitian Berkman, Cole, \& Fu (2009) menemukan bahwa perusahaan yang lebih kecil berpotensi lebih kecil untuk melakukan tunneling sehingga perusahaan yang lebih besar cenderung lebih mudah melakukan tunneling atas aset yang ada. Mustafa, et al. (2011) menyatakan bahwa perusahaan dengan ukuran perusahaan yang lebih kecil maka kemungkinan terjadinya tunneling juga lebih rendah. Penelitian Izzaty dan Kurniawan (2018) memberikan hasil bahwa ukuran perusahaan berpengaruh

positif terhadap pengungkapan transaksi pihak berelasi, dengan pengungkapan transaksi pihak berelasi maka potensi terjadinya tunneling semakin kecil.

\section{PROFITABILITAS}

Profitabilitas merupakan rasio untuk mengukur kemampuan perusahaan dalam menciptakan keuntungan, baik dalam bentuk laba perusahaan maupun 
dalam nilai ekonomis atas penjualan, aset bersih perusahaan maupun modal sendiri (shareholder equity) (Raharjaputra, 2009).Profitabilitas perusahaan yang tinggi menunjukkan efisiensi perusahaan dalam menggunakan modalnya untuk dapat beroperasi dalam menghasilkan laba sehingga potensi praktik tunneling menjadi lebih rendah. Argumen ini didukung dengan hasil penelitian Berkman, Cole, \& Fu (2009) bahwa perusahaan dengan tingkat profitabilitas dan pertumbuhan yang tinggi cenderung untuk terhindar dari praktik tunneling. Mustafa, et al. (2011) menyatakan bahwa tunneling lebih rendah terjadi pada perusahaan dengan profitabilitas yang lebih baik. Selain itu penelitian Apriani (2015) dan Izzaty dan Kurniawan (2018) juga menemukan bahwa profitabilitas berpengaruh signifikan pada pengungkapan transaksi pihak berelasi. Perusahaan dengan profitabilitas baik cenderung mengungkapkan transaksi pihak berelasi dengan baik sehingga meminimalkan praktik tunneling.

\section{KEBIJAKAN DIVIDEN}

Kebijakan perusahaan untuk membagikan laba kepada pemegang saham disebut disebut kebijakan dividen. Kebijakan dividen digunakan untuk mengurangi agency conflict antara principal dan agen berdasarkan agency theory - free cash flow hypothesis(Jensen, 1986). Teori ini yang mendasari penggunaan kebijakan dividen sebagai variabel moderasi.Faccio et al., (2001) yang menyebutkan bahwa kebijakan dividen sebagai sarana manajer untuk mengatasi masalah agensi yang timbul dari asimetri informasi dan kontrak yang tidak lengkap kepada pemegang saham. Pembayaran dividen membuat agen mengembalikan laba perusahaan kepada prinsipal dan tidak ada laba yang bisa dimanfaatkan secara pribadi oleh agen.

Kebijakan dividen dalam pandangan alternatif agency theory terbagi menjadi substitute model dan outcome model. Substitute model diterapkan pada Negara civil law yang perlindungan investornya rendah, dividen sebagai substitusi atas proteksi legal yang digunakan untuk membuat reputasi baik di 
mata investor bahwa perusahaan berusaha mengurangitunneling. Rasio kebijakan dividen pada negara civil law harus lebih tinggi agar reputasi perusahaan lebih baik (La-Porta et al., 2000). Sedangkan outcome model diterapkan pada Negara common law yang perlindungan investornya tinggi, dividen sebagai hasil corporate governance yang baik dalam rangka melakukan perlindungan legal pemegang saham.Hal ini menunjukkan bahwa dividen dapat digunakan untuk mengurangi risiko tunneling yang dilakukan oleh pemegang saham.

Pengujian hubungan corporate governance secara individual dengan kebijakan dividen pada 21 negara berkembang dilakukan oleh Connor (2012) menunjukkan dukungan terhadap outcome model yaitu,kebijakan dividen merupakan hasil tata kelola yang kuat dan kebijakan dividen lebih besar pada perusahaan dengan dewan independen dan akuntabilitas yang tinggi. Selain itu, peneliti juga menemukan sedikit bukti tentang substitute model pada perusahaan tertutup dengan membayar dividen lebih tinggi daripada perusahaan yang terbuka. Alternatif teori agensi berupa substitute model (pandangan substitusi) atas dividen yaitu perusahaan dengan perlindungan pemegang saham yang rendah akan membayar dividen lebih tinggi juga dibuktikan dari penelitian Cesari (2012) di Italia serta Qi (2013) di China.

\section{Pengembangan Hipotesis}

Berdasarkan uraian mengenai penelitian terdahulu tersebut, hipotesis penelitian yang dirumuskan adalah:

H1 : Corporate Governance berpengaruh terhadap praktik tunneling

$\mathrm{H} 2$ : Leverage perusahaan berpengaruh terhadap praktik tunneling

H3 : Ukuran perusahaan berpengaruh terhadap praktik tunneling

H4 : Profitabilitas perusahaan berpengaruh terhadap praktik tunneling

H5 : Kebijakan dividen memoderasi pengaruh corporate governance terhadap praktik tunneling 


\section{Gambar 3.1}

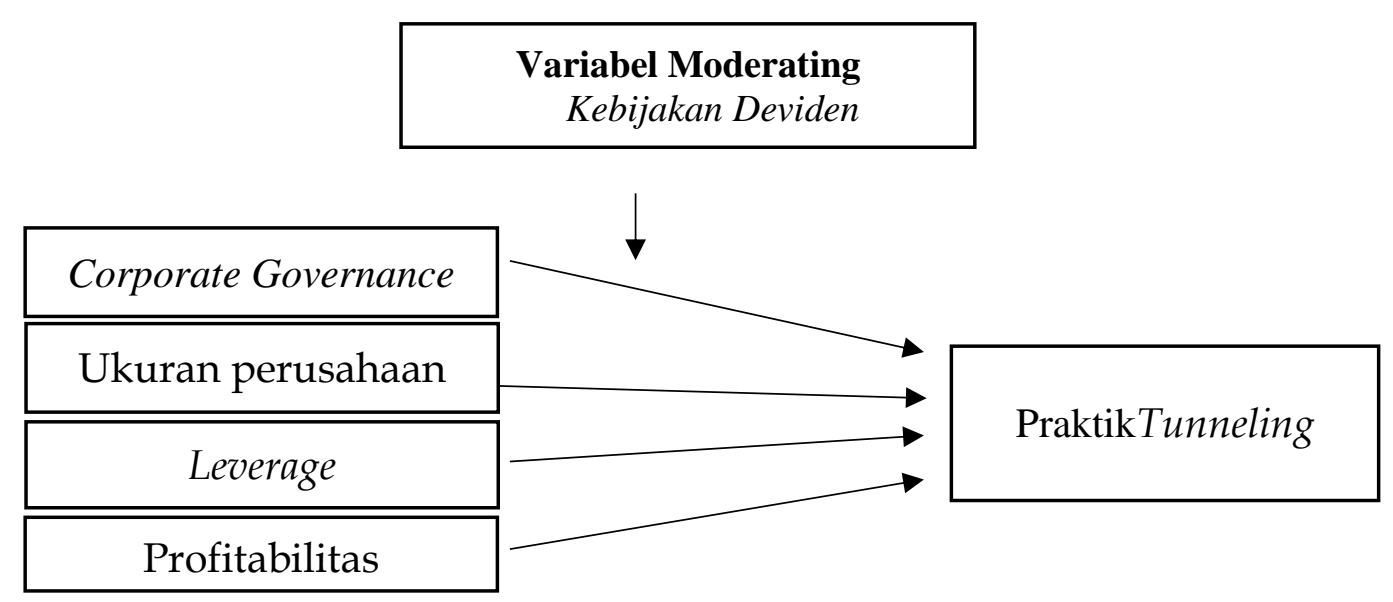

\section{METODE PENELITIAN}

Penelitian ini menggunakan pendekatan eksplanatoris -korelasional. Metode Pengumpulan data adalah dokumentasi. Jenis data penelitian berupa data sekunder yaitu berupa laporan tahunan perusahaan publik yang terdaftar di BEI pada tahun 2013-2017 yang diperoleh dari situs resmi Bursa Efek Indonesia (BEI), yaitu www.idx.co.id.

\section{Populasi dan Sampel}

Populasi dalam penelitian ini adalah perusahaan publik yang terdaftar di Bursa Efek Indonesia (BEI) dengan pemilihan sampel menggunakan judgment samplingdengan kriteria yaitu perusahaan publik yang BEI pada periode 20132017 secara berturut-turut, tidak dimiliki oleh negara atau Badan Usaha Milik Negara (BUMN), mata uang pelaporan dinyatakan dalam rupiah, melakukan pinjaman pihak berelasi, membagikan dividen selama tahun 2013-2017, tidak memiliki nilai ekuitas negatif dan tidak mengalami rugi. 


\section{Tabel 2}

\section{Definisi Operasional Variabel}

\begin{tabular}{lll}
\hline No & Variabel & Definisi Operasional \\
\hline 1 & Praktik Tunneling & total selisih atas piutang dan utang pihak \\
& & berelasi dibagi dengan total aset. \\
\hline 2 & Corporate governance & skor corporate governance dengan \\
& & pedoman yang dikembangkan oleh Forum \\
& & for Corporate Governance in Indonesia \\
& & (FCGI) berupa Corporate Governance Self - \\
& & Assessment Checklist (nilai 0-5 dari setiap \\
& & pertanyaan $\times$ bobot masing-masing \\
& & kategori) \\
\hline 3 & Kebijakan dividen & Total dividen kas per lembar saham t \\
\cline { 3 - 3 } & & Laba per lembar saham $\mathrm{t}-1$ \\
\hline 4 & Leverage & Total Utang \\
\hline 5 & Ukuran Perusahaan & Total Aset Total Aset \\
\hline 6 & Profitabilitas. & ROE $=\frac{\text { Laba bersih setelah pajak }}{\text { Total Ekuitas }}$ \\
\hline
\end{tabular}

\section{Metode Analisis Data}

Metode analisis data digunaan untuk menguji hipotesis penelitian digunakan metode analisis moderatedregression analysis (MRA). Sebelum dilakukan pengujian dengan Moderated Regression Analysis, dilakukan pengujian normalitas data, pengujian asumsi klasik yang terdiri pengujian Heterokedasitas, Autokorelasi, Multikolinearitas. Dalam analisis data dibantu dengan Software program SPSS18. 
Fakhriyyah E Mawardi: Model Penerapan Good...

HASIL PENELITIAN DAN PEMBAHASAN

Tabel 3

Hasil Moderated Regression Analysis

\begin{tabular}{|c|c|c|c|c|c|}
\hline Keterangan & Variabel & Koefisien & Signifikansi & $\mathbf{R}$ & Sig. $\quad F$ \\
\hline Persamaan 1 & Konstanta & 11,134 & 0,000 & \multirow{5}{*}{0,642} & \multirow{5}{*}{0,000} \\
\hline \multirow{4}{*}{ (Hipotesis 1) } & CG & $-0,082$ & 0,000 & & \\
\hline & Lev & 0,410 & 0,420 & & \\
\hline & Size & 0,376 & 0,003 & & \\
\hline & ROE & 0,831 & 0,000 & & \\
\hline Persamaan 2 & Konstanta & 12,522 & 0,000 & \multirow[t]{6}{*}{0,684} & \multirow[t]{6}{*}{0,002} \\
\hline \multirow{5}{*}{ (Hipotesis 2) } & CG & $-0,083$ & 0,000 & & \\
\hline & Lev & 0,153 & 0,555 & & \\
\hline & Size & 0,275 & 0,003 & & \\
\hline & ROE & 1,046 & 0,000 & & \\
\hline & DPR & $-0,330$ & 0,003 & & \\
\hline Persamaan 3 & Konstanta & 12,415 & 0,000 & \multirow[t]{7}{*}{0,684} & \multirow[t]{7}{*}{0,661} \\
\hline \multirow{6}{*}{ (Hipotesis 2) } & CG & $-0,073$ & 0,000 & & \\
\hline & Lev & 0,171 & 0,406 & & \\
\hline & Size & 0,260 & 0,004 & & \\
\hline & ROE & 1,042 & 0,000 & & \\
\hline & DPR & $-0,069$ & 0,897 & & \\
\hline & DPR *CG & $-0,007$ & 0,739 & & \\
\hline
\end{tabular}

Berdasarkan tabel di atas, persamaan regresi penelitian sebagai berikut:

$\mathrm{PE}=11,134-0,082 \mathrm{CG}+0,410 \mathrm{LEV}+0,376 \mathrm{SIZE}+0,831 \mathrm{ROE}+\varepsilon_{2}$

$\mathrm{PE}=12,522-0,083 \mathrm{CG}-0,330 \mathrm{DPR}+0,153 \mathrm{LEV}+0,275 \mathrm{SIZE}+1,046 \mathrm{ROE}+$ $\varepsilon_{2}$

$\mathrm{PE}=12,415-0,073 \mathrm{CG}-0,069 \mathrm{DPR}+0,171 \mathrm{LEV}+0,260 \mathrm{SIZE}+1,042 \mathrm{ROE}-$ $0,069 C G * D P R+\varepsilon_{3}$

\section{HASIL PENGUJIAN HIPOTESIS}

Model pengujian hipotesis ini telah memenuhi asumsi klasik berupa asumsi normalitas melalui pengujian Kolmogorov Smirnov, asumsi multikolinearitas melalui nilai tolerance dan VIF, asumsi heterokedastisitas melalui uji glejser, dan asumsi autokorelasi melalui nilai Durbin Watson 


\section{Pengaruh Corporate Governance terhadap Praktik Tunneling}

Pada tabel 3, diketahui bahwa variabel corporate governance memiliki nilai signifikansi sebesar $0,000(<0,05)$ dengan koefisien regresi sebesar 0,082 yang artinya hipotesis 1 diterima sehingga corporate governance berpengaruh negatif terhadap praktik tunneling. Dengan corporate governance yang semakin tinggi maka dapat menurunkan praktik tunneling. Hasil penelitian ini mendukung penelitian terdahulu yang dilakukan oleh Hamid et al., (2016), Hasnan et al., (2016), Matinfard et al., (2015), Hastori et al., (2015), Chen et al., (2014), Yeh et al., (2012), dan Lo, Wong, dan Firth (2010) yang menunjukkan bahwa corporate governance dapat mengurangi risiko praktik tunneling. Penggunaan transaksi pihak berelasi yang merugikan sebagai bentuk tunneling serta kemampuan corporate governance dalam mengatasi masalah transaksi pihak berelasi yang merugikan juga telah dibuktikan oleh Gordon, Henry, dan Palia (2004). Hasil penelitian ini tidak sejalan dengan penelitian Juliarto et al., (2013) dan Sari et al., (2014).

Konflik keagenan tipe 2 yang terjadi antara pemegang saham mayoritas dan minoritas yangberupa tunneling dalam melakukan transaksi pinjaman pihak berelasi dapat diatasi dengan menerapkan mekanisme corporate governance yang baik karena dapat memperhatikan hak dan kepentingan para pemangku kepentingan. Pengukuran mekanisme corporate governance menggunakan skor corporate governance yang mencakup hak pemegang saham, kebijakan corporate governance, praktik corporate governance, pengungkapan corporate governance, dan komponen audit terbukti mampu mengurangi praktik tunneling jika dibandingkan dengan penelitian-penelitian sebelumnya yang mengukur mekanisme corporate governance secara individual yang diperoleh hasil yang tidak konsisten. Penggunaan skor corporate governance dalam penelitian ini memberikan solusi untuk mengatasi 
Fakhriyyah \& Mawardi: Model Penerapan Good...

masalah agensi di Asia yang tidak dapat diatasi oleh mekanisme corporate governance konvensional berdasarkan penelitian Claessens dan Fan (2003)

\section{Pengaruh Leverage Terhadap Praktik Tunneling}

Pada tabel 3, variabel leverage memiliki nilai signifikansi sebesar 0,420 yang artinya hipotesis 2 ditolak sehingga leverage tidak berpengaruh terhadap praktik tunneling. Hasil penelitian ini sejalan dengan penelitian dari Utama dan Utama (2012) yang menyatakan bahwa financial leverage tidak berpengaruh terhadap pengungkapan transaksi pihak berelasi sebagai bentuk dari tunneling. Hal ini disebabkan karena leverage yang dilakukan murni untuk memperoleh sumber keuangan yang digunakan untuk menunjang operasional perusahaan.

\section{Pengaruh Ukuran Perusahaan Terhadap Praktik Tunneling}

Pada tabel 3, variabel ukuran perusahaan memiliki nilai signifikansi sebesar 0,003 hipotesis 3 diterima yaitu terdapat pengaruh ukuran perusahaan terhadap tunneling dan hasilnya berpengaruh positif yang artinya semakin besar ukuran perusahaan maka akan semakin besar pula potensi terjadi praktik tunneling. Hasil penelitian ini sejalan dengan penelitian Berkman, Cole, \& Fu (2009), Mustafa, Latif, \& Taliyang (2011),serta Izzaty dan Kurniawan (2018).

Pada perusahaan yang semakin besar terutama pada grup perusahaan maka semakin banyak sumber ekonomi yang harus diperoleh untuk menjalankan perusahan. Hal ini yang menyebabkan perusahaan melakukan praktik tunneling, selain itu lebih mudah pula melakukan praktik tunneling pada perusahaan besar karena kompleksnya informasi yang ada serta banyaknya aset yang dapat berpotensi disalahgunakan seperti tunneling.

\section{Pengaruh Profitabilitas Terhadap Praktik Tunneling}

Pada tabel 3, variabel profitabilitas memiliki nilai signifikansi 0,000 yang menunjukkan bahwa hipotesis 4 diterima yaitu profitabilitas berpengaruh terhadap praktik tunnelingdengan arah koefisien positif. Hal ini berlawanan 
arah dengan Berkman, Cole, \& Fu (2009) dan Mustafa, Latif, \& Taliyang (2011) yang memberikan hasil bahwa perusahaan dengan profitabilitas lebih rendah cenderung berpotensi melakukan praktik tunneling.

Perusahaan dengan profitabilitas yang tinggi cenderung melakukan praktik tunneling karena semakin baik profitabilitas maka pemegang saham mayoritas cenderung berkeinginan untuk mendapatkan keuntungan yang lebih banyak pula sehingga pemegang saham mayoritas dapat mengatur untuk melakukan transaksi yang berpotensi terjadinya tunneling.

\section{Peran Kebijakan Dividen dalam Memoderasi Pengaruh Tata Kelola Terhadap Praktik Tunneling}

Berdasarkan Tabel 3 pada model regresi 2, signifikansi variabel kebijakan dividen sebesar 0,003 dan koefisien regresi sebesar -0,330. Hasil pengujian tersebut menunjukkan bahwa kebijakan dividen berpengaruh negatif terhadap praktik tunneling.Pengujian selanjutnya adalah kebijakan dividen sebagai variabel moderasi yang berinteraksi dengan variabel corporate governance. Berdasarkan hasil pengujian model regresi 3 di Tabel 3, koefisien regresi untuk variabel interaksi sebesar -0,007 dengan signifikansi t sebesar 0,739, pada model regresi 2 nilai $R^{2}$ sebesar 0,684, sedangkan nilai $R^{2}$ model regresi 3 juga sebesar 0,684 , tidak terdapat perubahan nilai $R^{2}$ serta memiliki nilai signifikansi f change pada model regresi 3 sebesar 0,661 (melebihi tingkat signifikansi $5 \%$ ) yang dapat disimpulkan bahwa variabel kebijakan dividen tidak dapat memoderasi corporate governance terhadap praktik tunneling sehingga hipotesis 5 ditolak, namun kebijakan dividen berpengaruh negatif terhadap praktik tunneling.

Hal ini menunjukkan bahwa kebijakan dividen mampu menurunkan praktik tunneling namun tidak mampu memoderasi pengaruh corporate governance terhadap praktik tunneling.Kebijakan dividen di Indonesia tidak berdasarkan pada outcome model namun mendukung substitute model yang memang diterapkan pada Negara civil law seperti Indonesia.Kebijakan dividen di 
Indonesia digunakan sebagai pengganti atas corporate governance yang kurang mampu mengatasi masalah tunneling serta menjadi sarana yang baik untuk membangun reputasi perusahaan.

Kebijakan dividen sebagai substitusi mekanisme corporate governance sesuai dengan penelitian Qi (2013) yang menyatakan bahwa kebijakan dividen sebagai substitusi proteksi legal investor kecil dan menengah. Hal ini juga diperkuat oleh penelitian Benjamin dan Zain (2015) yang di Malaysia yang menunjukkan hubungancorporate governance dengan kebijakan dividen di Malaysia merupakan hubungan substitusi bukan pelengkap.

Hasil penelitian ini menolak pandangan agency theory - free cash flow hypothesis. Motivasi perusahaan di Indonesia membagikan kebijakan dividen tidak berdasarkan arus kas bebas namun karena faktor lain yang di tetapkan dalam RUPS (Juhandi et al., 2011). Lestari (2012) meneliti kebijakan dividen di Indonesia yang hasilnya bahwa kebijakan dividen dibayarkan oleh perusahaan yang telah dewasa daripada perusahaan yang bertumbuh, yang mana perusahaan di Indonesia mayoritas masih dalam fase bertumbuh, sehingga penelitian ini mendukung agency-based life cycle theory. Hal ini sejalan dengan penelitian Wardhana, Tandelilin, Lantara, dan Junarsin (2014) yang mendukung penerapan life cycle theory atas kebijakan dividen di Indonesia. Dapat disimpulkan bahwa agency theory - free cash flow hypothesis kurang sesuai diterapkan di Indonesia karena perbedaan fase hidup perusahaan di Indonesia dibandingkan dengan negara-negara yang sudah maju.

\section{SIMPULAN}

Hasil penelitian ini memberikan bukti empiris bahwa praktik tunneling dipengaruhi oleh ukuran perusahaan dan profitabilitas, sebaliknya leverage tidak berpengaruh terhadap praktik tunneling, namun praktik tunneling dapat diminimimalisasi dengan penerapan corporate governance yang baik. Perusahaan yang menerapkan corporate governance yang baik dapat 
memberikan perlindungan terhadap pemegang saham karena memperhatikan kepentingan dan hak semua stakeholder sehingga dapat meminimalisir praktik tunneling yang merugikan pemegang saham minoritas.

Penelitian ini juga memberikan bukti empiris bahwa kebijakan dividen tidak dapat memoderasi corporate governance dalam mengatasi praktik tunneling karenakebijakan dividen hanya digunakan sebagai substitusi ketika mekanisme perlindungan pemegang saham lain tidak maksimal dilakukan. Dengan demikian penelitian ini tidak dapat membuktikan agencyfree cash flow hypothesis.

Keterbatasan penelitian adalah bahwa beberapa perusahaan kurang rinci dalam menjelaskan praktik corporate governance serta beberapa item dibutuhkan subjektivitas penilaian sehingga penilaian item-item tertentu dapat berbeda setiap peneliti. Saran bagi peneliti selanjutnya bisa mempertimbangkan sumber lain selain laporan tahunan dalam melakukan penilaian corporate governance perusahaan misalnya dengan mencari beritaberita pada situs perusahaan sehingga kemungkinan mendapatkan informasi penerapan corporate governance tertentu menjadi lebih baik.

\section{DAFTAR PUSTAKA}

Apriani, Werdi Halim. (2015). Pengaruh Corporate Governance Dan Karakteristik Perusahaan Terhadap Luas Pengungkapan Transaksi Pihak Berelasi Di Indonesia.Jurnal Akuntansi Indonesia. 4, 36 - 50

Benjamin, S. J., \& Zain, M. M. (2015). Corporate Governance and Dividends Payout: Are They Substitutes or Complementary ? Journal of Asia Business Studies, 9(2), 177-194.

Berkman, H., Cole, R. A. dan Fu, L.J. (2009). Expropriation Through Loan Guarantees to Parties: Evidence from China. Journal of Banking and Finance, 33, 141-156. 
Fakhriyyah \& Mawardi: Model Penerapan Good...

Cahyani, Krisnati Adi., dan Sanjaya I.P.S. Analisis Perbedaan Dividen Pada Perusahaan Keluarga Dan Non Keluarga Berdasarkan Kepemilikan Ultimat. Modus Journal, 26(2).

Cesari, A. De, (2012). Expropriation of Minority Shareholders and Payout Policy.The British Accounting Review, 44(4), 207-220.

Chen, Y., Wang, Y., \& Lin, L. (2014). Independent Directors' Board Networks and Controlling Shareholders' Tunneling Behavior. China Journal of Accounting Research, 7, 101-118.

Cheung, Y.-L., Jing, L., Lu, T., Rau, P. R., \& Stouraitis, A. (2009). Tunneling and Propping Up: An Analysis of Related Party Transactions by Chinese Listed Companies. Pacific Basin Finance Journal, 17(3), 372-393.

Claessens, S. dan Fan, J.P.H., (2003). Corporate Governance in Asia: A Survey. International Review of Finance, 3(2), 71-103.

Connor, T. O. (2012). Dividend Payout and Corporate Governance in Emerging Markets: Which Governance Provisions Matter?

Faccio, B. M., Larry, H., Lang, P., \& Young, L. (2001). Dividends and Expropriation. The American Economic Review, 91(1), 54-78.

Friedman, E., Johnson, S., \& Mitton, T. (2003). Propping and Tunneling. Journal of Comparative Economics, 31, 732-750.

Gordon, E. A., Henry, E., \& Palia, D. (2004). Related Party Transaction and Corporate Governance. Advance in Financial Economics, 9(04), 1-27.

Hamid, M. A., Ting, I. W. K., \& Kweh, Q. L. (2016). The Relationship Between Corporate Governance and Expropriation of Minority Shareholders' Interest. Procedia Economics and Finance, 35(16), 99-106. https://doi.org/10.1016/S2212-5671(16)00014-9

Halim, Lucia Meliana dan Wardhani, Ratna.(2013). Analisis Pengaruh Konflik Keagenan terhadap Kebijakan Dividen. Lib.ui.ac.id

Hasnan, S., Daie, M. S., \& Hussain, A. R. M. (2016). Related Party Transactions and Earnings Quality: Does Corporate Governance Matter? International 
Journal of Economics and Management, 10(April 2015), 189-219. Hastori, Siregar, H., Sembel, R., \& Maulana, T. N. A. (2015). Agency Costs , Corporate Governance and Ownership Concentration: The Case of Agroindustrial Companies in Indonesia. Asian Social Science, 11(18), 311-319. Izzaty, Khairina Nur dan Kurniawan, Pratomo Cahyo.(2018). Pengaruh Kinerja

Keuangan, Struktur Kepemilikan Dan Corporate Governance Terhadap Tingkat Kepatuhan Pengungkapan Transaksi Pihak Berelasi Pasca Konvergensi Ifrs. JWEM STIE MIKROSKIL, 8(2).

Jensen, M. C. (1986). Agency Costs of Free Cash Flow, Corporate Finance, and Takeovers. The American Economic Review, 76(2), 323-329.

Jensen, M. C., \& Meckling, W. H. (1976). Theory of The Firm: Managerial Behavior, Agency Costs and Ownership Structure. Journal of Financial Economics, 3(4), 305-360.

Johnson, S., La Porta, R., Lopez-De-Silanes, F., \& Shleifer, A. (2000). Tunnelling. American Economic Review, 90(2), 22-27.

Juhandi, N., Sudarma, M., Aisjah, S., \& Rofiaty. (2011). The Effects of Internal Factors and Stock Ownership Structure on Dividend Policy on Company's Value [A Study on Manufacturing Companies Listed on the Indonesia Stock Exchange ( IDX )]. International Journal of Business and Management Invention, 2(11), 6-18.

Juliarto, A., Tower, G., Zahn, M. Van der, \& Rusmin, R. (2013). Managerial Ownership Influencing Tunnelling Behaviour. Australasian Accounting, Business and Finance Journal, 7(2), 25-46.

Kultys, J. (2016). Controversies About Agency Theory as Theoretical Basis for Corporate Governance. Oeconomia Copernicana, 7(4), 613-634.

La-Porta, R., Lopez-de-silanes, F., Shleifer, A., dan Vishny, R., (2000).Investor Protection and Corporate Governance.Journal of Financial Economics, 58, 3-27.

Lestari, J. S. (2012). Determinants of Dividend Decision: Evidence from the 
Fakhriyyah \& Mawardi: Model Penerapan Good...

Indonesia Stock Exchange. Review of Integrative Business \& Economics Research, 1(1), 346-355.

Lo, A.W.Y., Wong, R.M.K. dan Firth, M., (2010). Can corporate governance deter management from manipulating earnings? Evidence from relatedparty sales transactions in China.Journal of Corporate Finance, 16(2), 225-235.

Matinfard, M., Hassani, M., \& Elyasi, H. (2015). Reviewing Role of Corporate Governance Regarding Transactions With Related Parties and Company Performance Among Companies Admitted Into Tehran Stock Exchange. Ciência ENatura, 37(2), 45-53.

Mustafa, Nurul Huda,. Latif, Rohaida Abdul., and Taliyang, Siti Mariana. (2011). Expropriation Of Minority Shareholders' Rights: Evidence From Malaysia. International Journal of Business and Social Science, 2(13).

Nurazi, R., Santi, F., \& Usman, B. (2015). Tunnelling: Evidence From Indonesia Stock. Asian Academy of Management Journal of Accounting and Finance, 11(2), 127-150.

Pratiwi, Bela. (2018). Pengaruh Pajak, Exchange Rate, Tunneling Incentives, dan Leverage terhadap Transfer Pricing. Jurnal Ekonomi dan Bisnis. 29 (3).

Qi, W. (2013). Corporate Governance and Cash Dividend Policy in China: An Empirical Analysis. Ais Electronic Library, 16, 166-174.

Raharjaputra, Hendra. S. (2009). Manajemen Keuangan dan Akuntansi. Jakarta: Salemba Empat.

Sari, R.C., Djajadikerta, H.G. dan Baridwan, Z., (2014). Asset Tunneling: Does Corporate Governance Matter? Evidence from Indonesia.

Su, Z., Fung, H., Huang, D., \& Shen, C. (2014). Cash Dividends, Expropriation, and Political Connections: Evidence from China. International Review of Economics and Finance, 29, 260-272.

Utama, Cynthia A. and Utama, Sidharta. 2012. Determinants of disclosure 
level of relatedparty transactions in Indonesia, 11, pp 74-98.

Wardhana, L. I., Tandelilin, E., Lantara, I. W. N., \& Junarsin, J. E. (2014). Dividend Policy in Indonesia: A Life-Cycle Explanation.

Yeh, Y., Shu, P., \& Su, Y. (2012). Related-party Transactions and Corporate Governance: The Evidence From the Taiwan Stock Market. Pacific-Basin Finance Journal, 20(5), 755-776 